\title{
An Analysis of Scientific Articles on Science Misconceptions: A Bibliometric Research
}

\author{
Muhammed Akif KURTULUŞ, Alanya Alaaddin Keykubat University, Turkey, \\ muhammed.kurtulus@alanya.edu.tr, ORCID: 0000-0001-5206-5787 \\ Nilgün TATAR, Alanya Alaaddin Keykubat University, Turkey, nilgun.tatar@alanya.edu.tr, ORCID: 0000- \\ 0002-7452-5323
}

\begin{abstract}
The aim of the study is to conduct a bibliometric analysis of the published articles related to science misconceptions. For this purpose, bibliometric analyses have been carried out with 859 articles published in physics, chemistry, and biology education between 1986 and 2019. The articles have been obtained through Web of Science Core Collection database using "science misconceptions" keyword and the tendencies in the last 33 years are presented. The selected articles were put through bibliometric analysis to identify the results for the annual distributions of the articles; the average citation scores; the list of the journals that published the highest number of related articles; the list of the authors that had published the highest number of related articles; the citation burst scores of the authors; the scientific productivity of the countries of the authors; the articles that were cited at the highest rates; collaboration networks; and their patterns that were obtained through text mining methods of word cloud and word tree. The results indicate that there has been an increase in the interest in science misconceptions after 2010. The journal that has the highest number of publications on the issue is found to be Journal of Science Education while David F. Treagust is identified to have the highest number of articles published on the topic so far. The article that has been cited the highest is Furtak's article published in 2012. The findings also show that Korea and China are the countries that are open to collaboration the most and that the most frequently used keywords are determined to be "science" and "students". The results are meant to guide researchers in the field in their future studies.
\end{abstract}

Keywords: Science misconception, bibliometric analysis, R-studio

Received: 29.02.2020 Accepted: 16.07.2020 Published: 01.15.2021

\section{INTRODUCTION}

Everyone thinks about how the world we live in works, how we communicate with it, how it constantly changes and what the reasons behind those changes are. These thoughts are our personal concepts developed to understand our surrounding (Gooding \& Metz, 2011). Concepts are the constituent of knowledge that help individuals to relate a piece of information to other pieces or to distinguish it from others. Thus, they play a crucial role in the process of thinking and learning. Understanding the concepts and establishing relationships among them underlie meaningful learning. Establishing relationships among concepts is a necessary process for forming new conceptualizations (Berkant, 2007). Individuals develop concepts through the experiences they have while exploring their physical and social world (Allen \& Coole, 2012). Some of these concepts can be correct while others could be wrong (Gooding \& Metz, 2011). These wrong concepts developed before formal schooling could contradict with what they learn at school (Allen \& Coole, 2012). These clashes have been referred to using different terminology by researchers such as "preconceptions" (Novak, 1977); "alternative conceptions" (Driver \& Easley, 1978); "misconceptions" (Helm, 1980); "children's scientific intuitions" (Sutton, 1980); "children's science" (Gilbert, Watts, \& Osborne, 1982); "common sense concepts" (Halloun \& Hestenes, 1985); or "spontaneous knowledge" (Pines \& West, 1986, cited in Eryilmaz, 2002). In the present article "misconceptions" will be used to refer to learners' ideas that are inconsistent with scientific ideas (Larkin, 2012).

Misconceptions are a part of a wide information system that involves inter-related concepts used by individuals to make sense of and explain daily experiences (Southerland et al. 2001). When an individual encounters new knowledge, he or she establishes associations between the new and the already existing knowledge. If the new input does not match the 
existing knowledge, then the existing constructs are restructured. The individual may unknowingly create and foster misconceptions by making explanations, solving problems, or even by providing evidence generated by erroneous reasoning. These misconceptions could be merged with other misconceptions or mistakes and thus, form an ongoing cycle (Wesson, 2001). As misconceptions are considered to be deep-reaching and resist to overcome even after instruction (Eryilmaz, 2002), research in the field has focused on finding out the reasons of this resistance and developing instructional methods and strategies that enable educators to change them (Sinatra, 2005).

Misconceptions that are frequently encountered in various domains of science (GomezZwiep, 2008) can develop as a result of factors independent of culture, age, gender, or any other personal characteristic. Among these factors, reasons such as learners' observations and experiences, their prejudices, religious or mythological teachings in their surroundings, inaccurate or unquestioned explanations given in a local language in science lessons have been reported in the literature (Committee on Undergraduate Science Education, 1997). Besides, misconceptions are often supported and strengthened not only by the learners themselves but by parents, teachers, media, science curricula, textbooks, and other teaching materials as well (Gooding \& Metz, 2011).

Misconceptions, which refer to the representations or conceptions acquired mostly in informal settings, hinder meaningful learning. Therefore, Allen (2010) advices teachers to start their lessons by uncovering learners' previously gained ideas about the science concepts related to topic to be studied at any given lesson. It is also important that researchers identify what learners' misconceptions in science are, how they are formed, the sources of these misconceptions, and how they can be overcome. Pioneering this line of research, Piaget (1929) introduced the clinical interview method, which was later adapted by educators to explicate learners' ideas in various science content areas (cited in Akerson, Flick \& Lederman, 2000). Huang (1931), for instance, used clinical interview method to find out how children explain different physical phenomena and identified their initial conceptions. This was followed by numerous studies conducted at all stages of education to determine learners' ideas related to science topics. For example, Allen (2010) investigated students' misconceptions in biology, chemistry, and physics at primary education. Duit (2002), on the other hand, inquired learners' misconceptions on science content areas such as the electric circuit, force, energy, combustion, and evolution. The findings of these studies indicated that learners' misconceptions can prevail all through school life and hinder meaningful learning.

In addition to the articles focusing on investigating and identifying misconceptions, there are also a considerable number of studies in the related literature aiming at finding ways to correct learners' misconceptions. The results of some of these studies indicate that misconceptions can be difficult to change and present a challenge to be overcome (Sinatra, 2005). Many of these studies attempted to transfer learners' misconceptions into correct ones through the use of various teaching strategies and materials. It has been frequently reported that learners in science education very often have inaccurate or immature conceptions related to scientific phenomena in physics, chemistry, astronomy, or engineering; and these are more likely to conflict with the new knowledge they are taught at schools. Therefore, many studies have investigated conceptual change or restructuring of existing knowledge (Sinatra, 2005). In order to substantiate change in learners' conceptions, it is crucial to address misconceptions and to provide necessary conditions for change. These conditions have been explained by Posner et al. (1982); and thereupon, many studies based on the conceptual change model have been carried out with the aim to overcome learners' misconceptions (Mason et al., 2017; Erduran, Kaya \& Cetin, 2018; Eymur \& Geban, 2017; Treagust, Duit, \& Fischer, 2017). Lin et al. (2016) analysed the studies that focus on the effects of conceptual change on learners' learning processes and outcomes and reported the strategies used in conceptual change and their effects on the process of overcoming misconceptions.

The significant amount of research conducted to identify misconceptions so far points out to the importance of the issue. Researchers have been exploring misconceptions and there have been numerous studies on misconceptions in science lessons conducted with various age 
groups (from pre-school stages up to higher education levels) focusing on affective traits as well as cognitive levels of learners. In this respect, it is important for researchers to recognize the leading researchers on the subject matter and to review their studies.

The aim of this study is to introduce the leading researchers on the matter, to present their work, to list the journals that have published related research, and to compile the common keywords used to search about misconceptions. With this purpose in mind, using Web of Science Core Collection database, the articles that have been published in educational journals on misconceptions in physics, chemistry, and biology were reached through "science misconception" keyword and were analysed to explore their biometrical features. This study is meant to guide researchers in analyzing studies conducted in the related field and to introduce them the research and the researchers on the related topic. It provides important information for researchers interested on misconceptions regarding the journals that publish articles on the topic. Also, the study presents guidance on which key concepts can be used when scanning related research on databases. As this study is the first in terms of providing demographic information on "science misconception" in the field, it is expected to assist researchers and contribute to their studies. The findings are meant to guide researchers through further studies on the subject matter.

Bibliometric research enables journals to shape publication policies by performing internal evaluation. Similarly, it helps researchers by accumulating data on the publications related to their research areas (Al, Soydal, \& Yalçın, 2010). Bibliometric analyses are considered to be of avail for researchers when identifying and evaluating the publications' organizations, countries, subject areas, related journals, and specific research topics (Huang, Ho, \& Chuang, 2006). Bibliometric research and meta-analysis research are different methods. While metaanalysis research aims to arrive at a single general conclusion by bringing the conclusions of different studies together and analyzing them systematically (Dinçer, 2014), bibliometric research is based on analyzing different studies bibliographically. Bibliometric analysis is a method that helps to summarize and to interpret existing information. Literature presents a good number of bibliometric studies (Hernandez-Torrano \& Ibrayeva, 2020; Jimenez, Prieto, \& Garcia, 2019; Özkaya, 2019; Doğru, Güzeller, \& Çelik, 2019; Tang, Hsiao, \& Su, 2019; Ye, Chen, \& Kong, 2019; Jho, 2018; Khodabandelou, Mehran, \& Nimehchisalem, 2018; Altınpulluk, 2018; Lopes, Fidalgo-Neto, \& Mota, 2017).

\section{METHODS}

The study is designed following descriptive research method, which is defined as a method used to explain the existing characteristics of events, phenomena or states (Büyüköztürk, Kılıç-Çakmak, Akgün, Karadeniz, \& Demirel, 2017). The present study describes the characteristics of the articles related to "science misconception". It is reached all the articles in the fields of science, physic, chemistry and biology teaching that include "science misconception" concept. It is clear that concepts such as "alternative concepts", "misunderstanding", and "child science" are used by some researchers to refer to misconceptions, this study aims to reach all the studies in the database through the single key concept specified: 'misconception', which seems the one used most commonly in the related literature.

\section{Sampling Method}

The data for the study was comprised of the published articles reached through using "science misconception" keyword in Web of Science Core Collection database. These articles have been published in various journals between 1986 and 2019. During the scanning in the database, books, book chapters, review articles, editorial materials and letters were excluded in the analyses. For the purpose of the study, only journal articles were included in the sample. As a result of the scanning, it was found that the first article on the subject matter was published in 1986; therefore, 1986 is considered to be the starting date for this line of research. Since 2020 has not finished yet, it was thought that including the articles published in 2020 so far may affect 
the results of the analyses; thus, these articles were also excluded from the sample of the study. The most important sources in bibliometric analyses are regarded to be Science Citation Index (SCI), Social Science Citation Index (SSCI) and Art \& Humanities Citation Index (A\&HCI) international citation indexes. In this respect, as Web of Science Core Collection database provides access to these indexes (Güzeller \& Çeliker, 2017) and as it is compatible with the bibliometric analysis system run through R-Studio program, WoS was chosen as the database to carry out the present research.

\section{Data Collection}

The database was scanned using "science misconception" keyword and 2596 publications in total were gathered. In line with the purpose of the study, some search limitations such as journal article, subject fields (science, physics, chemistry and biology teaching), and time period were set and accordingly, 859 articles were obtained and included in the analyses. This sample of articles were analysed to identify the results for the annual distributions of the articles; the average citation scores; the list of the journals that published the highest number of related articles; the list of the authors that had published the highest number of related articles; the citation burst scores of the authors; the scientific productivity of the countries of the authors; the articles that were cited at the highest rates; collaboration networks; and their patterns that were obtained through text mining methods of word cloud and word tree.

\section{Data Analysis}

The scanned articles were analysed using R-Studio program within the scope of the research. $\mathrm{R}$ program was accessed at https://cran.r-project.org/, which is the official storage website of many bibliometric analysis packages. These package programs for bibliometric analyses are quite beneficial in quantitative research (Aria \& Cuccurullo, 2017). Since R program provides more variety of results with enriched details, $\mathrm{R}$ program was chosen for the bibliometric analyses conducted in the present research.

The data file used for the study was formed through Web of Science Core Collection data based on the criteria identified for the research and following specific steps for the selection of the articles. The first was to select "export", next "other file formats", then "records from (1500)", and finally "record content (Full Record and Cited References)". The data file for the study after completing the selection steps consisted of 859 articles in total. However, since the system allows downloading maximum 500 articles, "plain text" option was selected to download the first 500 articles; and the other articles from 501 to 859 were downloaded separately. Then, both groups of articles were combined for the analyses. To analyse the articles, first, the "bibliometrix" package in R program was downloaded and activated for the analyses. Then, RStudio program was directed through a web address to bibliometric analysis page. Here, the "plain text" file was saved into data segment where the analyses of the study were conducted.

Bibliometric laws and bibliometric models are the rules established based on various statistical calculations and distributions in order to evaluate research processes of authors. These laws are generally simple mathematical and statistical functions that analyze the correlation of a variable with another variable (Karaboğa, 2019). In bibliometric science, there are five laws to determine the bibliometric productivity. These are Lotka Law, Bradford Law, Zipf Law, Price Law and Pareto law. In the present study, Bradford law was evaluated in terms of compatibility. The reason for excluding the evaluation of the other laws is first that all laws have the same focus, and second, that R-Studio program provides statistical information with visuals on Bradford law. Bradford Law which is also referred to as the distribution law is considered in the study. In one of his studies in the field of geophysics, Bradford reached to 326 journals in total. Bradford tried to explain the correlation for his study by using $1: \mathrm{n}^{\mathrm{n}} \mathrm{n}^{2}$ equation. The first group includes the smallest number of related journals but with the most important ones that are considered "core sources". While the second group covers a higher number of journals, the third group includes the journals with the lowest impact rates (Bookstein, 1980). In our study, the first group consisted of four journals considered to be core sources with 305 articles on science misconception. The second group had eight journals with 283 articles whereas the third group included 37 journals with 271 articles in total. It is believed that the study conducted by 
scanning with the key concept of "Science misconception" complies with Bradford Law. Graph 1 displays the source clustering through Bradford's law.

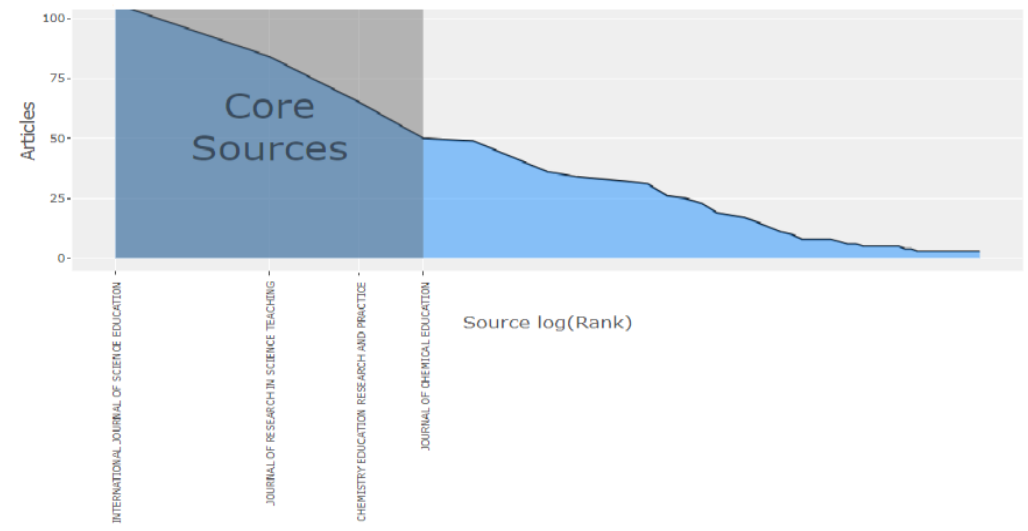

GRAPH 1.Source clustering through Bradford's law

\section{RESULTS}

The number of the articles published on misconceptions in the field of science is 859 , and Table 1 displays the distribution of the articles by years.

Table 1.Number of research articles by years

\begin{tabular}{ccc}
\hline Years & Number of Articles (f) & Percentage (\%) \\
\hline $1986-1990$ & 6 & 0.70 \\
$1991-1995$ & 28 & 3.25 \\
$1996-2000$ & 41 & 4.77 \\
$2001-2005$ & 60 & 6.98 \\
$2006-2010$ & 161 & 18.75 \\
$2011-2015$ & 307 & 35.74 \\
$2016-2019$ & 256 & 29.81 \\
\hline
\end{tabular}

As Table 1 shows, articles related to misconceptions in science started to be published in 1986 and the highest frequency was reached between 2011 and 2015 ( $\mathrm{f}=307$ ). The articles published after 2010 constituted $65.75 \%$ of the total articles. The annual average scores of citations are displayed in Graph 2.

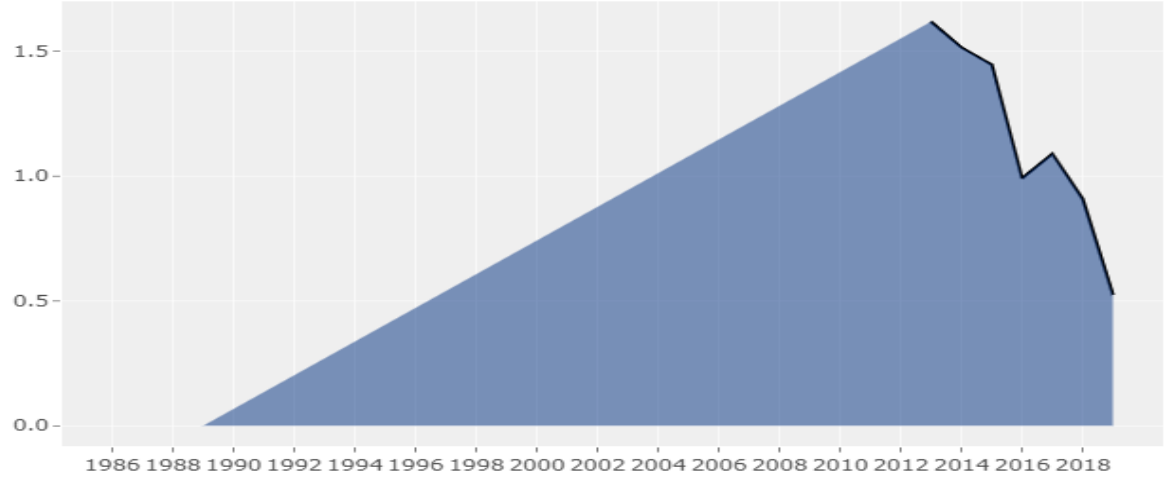

GRAPH 2.Annual average of citations

As shown in Graph 2, the highest increase in the annual average citations is in 2013. Graph 3 displays the journals in which the articles on the key concept were published. 


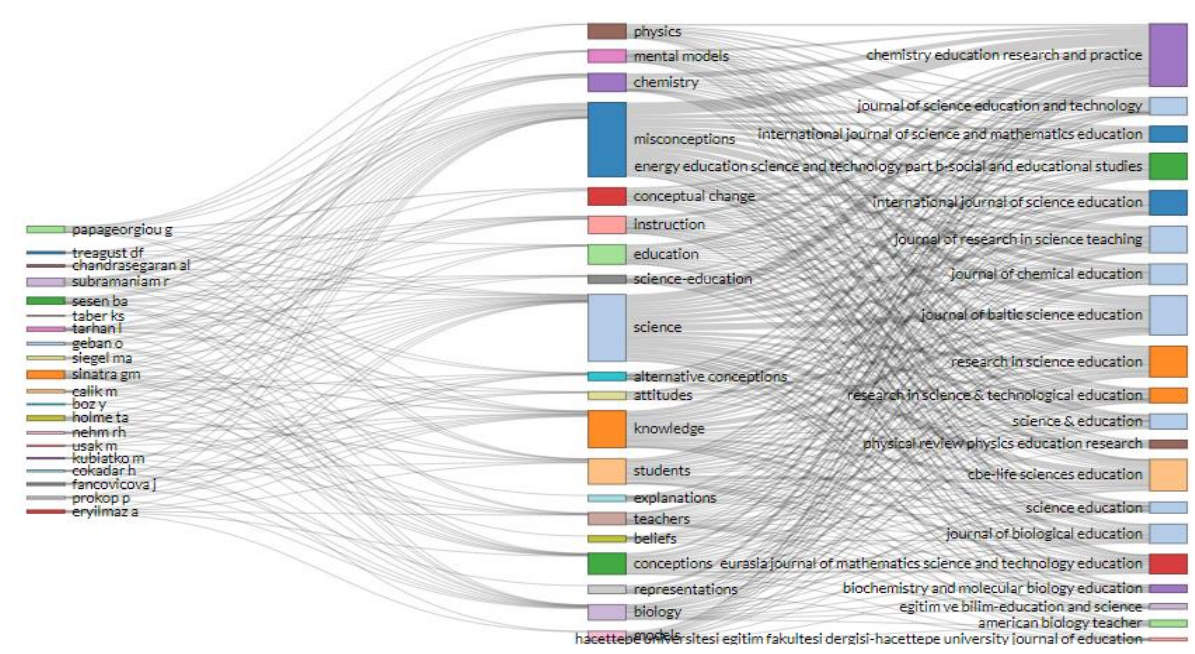

GRAPH 3. Three fields plot

According to Graph 3, the majority of the authors using "science misconception" had their articles published in all of the journals cited in the graph. Graph 4 shows the first 20 journals in the rank of the publications.
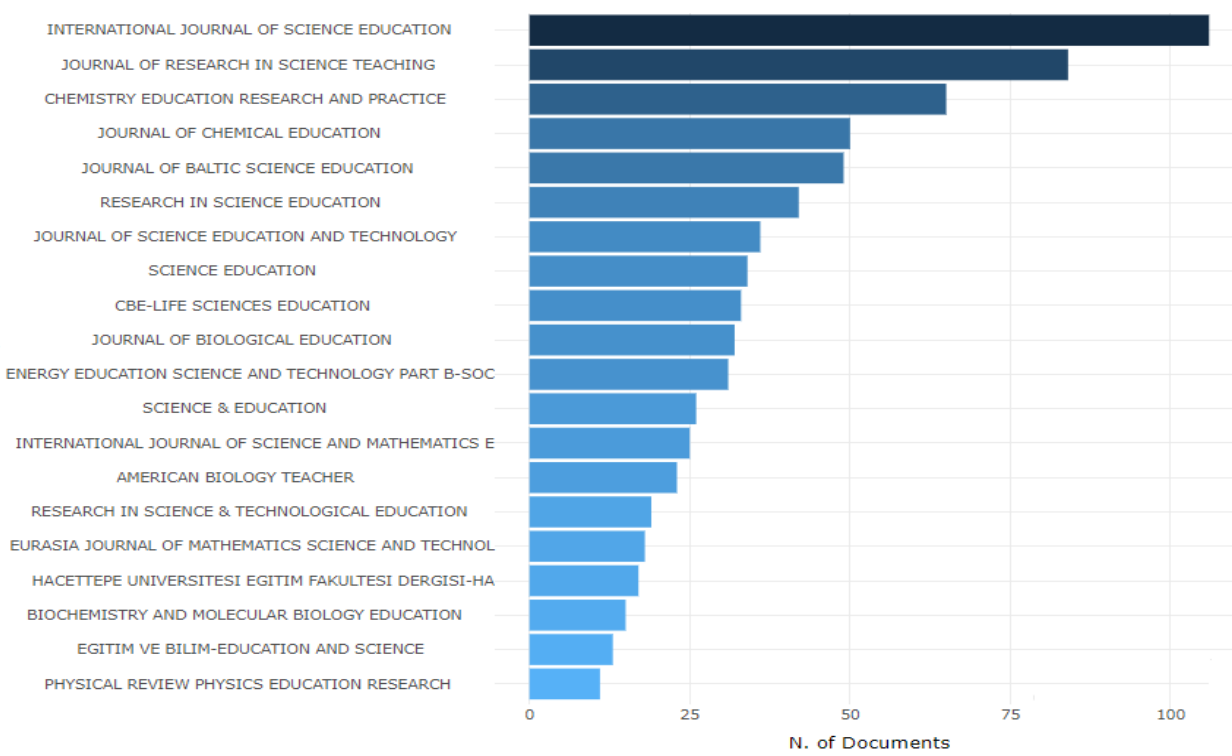

GRAPH 4. Journals with the highest number of published articles on science misconception

As shown in Graph 4, among the scanned journals using "science misconception" keyword, it has been found that the highest number of published articles belong to International Journal of Science Education ( $\mathrm{f}=106)$, Journal of Research in Science Teaching ( $\mathrm{f}=84$ ) and Chemistry Education Research and Practice ( $\mathrm{f}=65$ ). Graph 5 displays the authors with the highest number of articles published on the subject matter. 


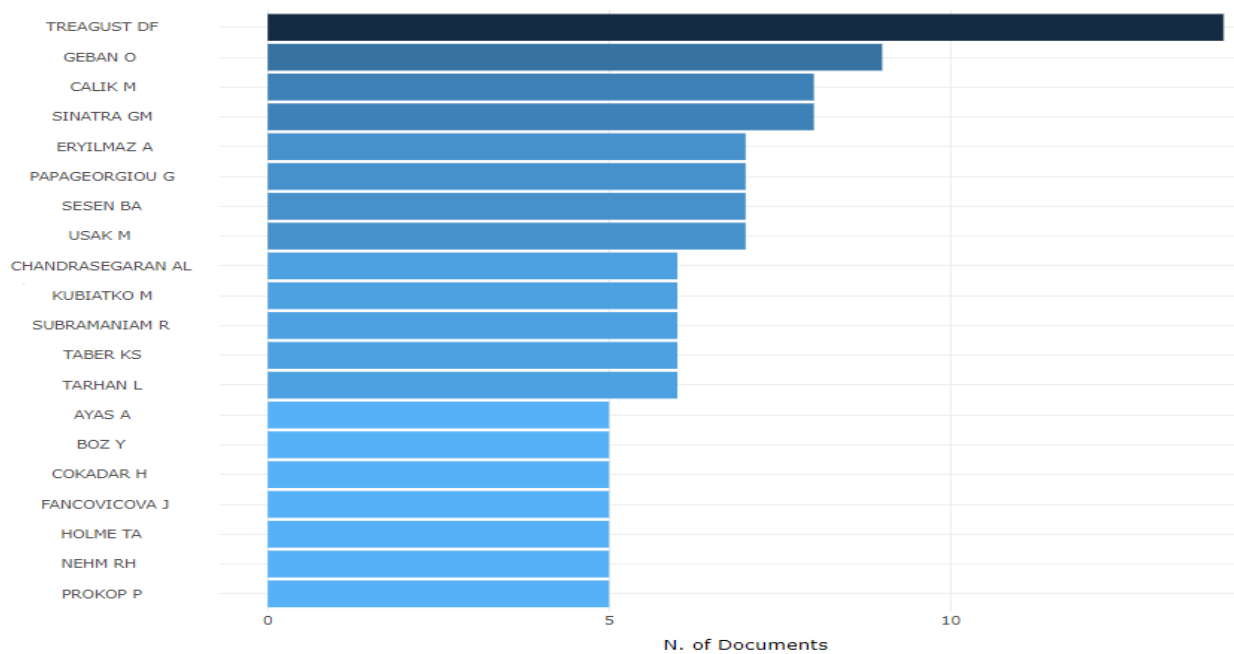

GRAPH 5. Authors with the highest number of publications on science misconception

As displayed in Graph 5, the highest number of published articles on "science misconception" belongs to David F. Treagust ( $f=14$ ) from Curtin University in Australia, followed by Ö. Geban ( $\mathrm{f}=9$ ) from Middle East Technical University in Turkey and M. Çalık $(\mathrm{f}=8)$ from Trabzon University in Turkey. Graph 6 presents the authors' scores of citation bursts.

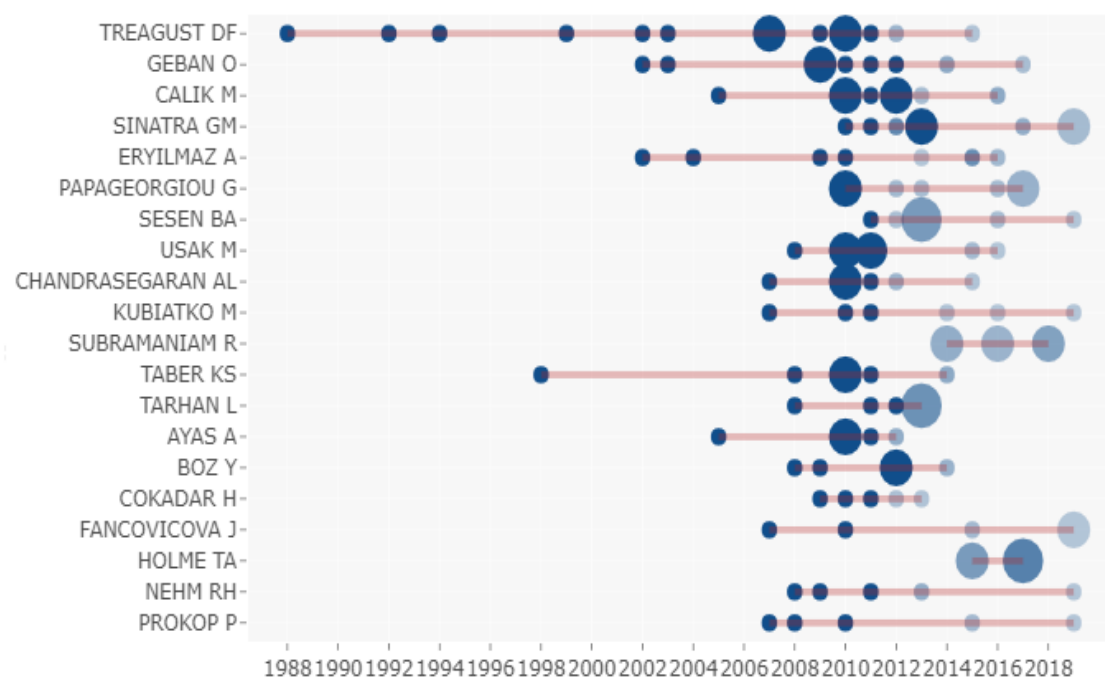

GRAPH 6.Scores of citation bursts

Regarding the authors' burst scores, it can be seen that Gale M. Sinatra has the highest burst score (12.25) between 2010 and 2019. It should be noted that Sinatra is not the author with the highest number of citations; rather, he was the most frequently cited author in the year when citation burst happened. It can also be seen that David F. Treagust was the leading author in the field during the 27 years from 1988 up to 2015. This results from the fact that he was cited every year continuously from 1988 until 2015. Table 2 displays the top four researchers with the highest citation burst scores.

Table 2.Citation burst scores per author and durations

\begin{tabular}{cccc}
\hline Authors & Burst & Start & End \\
\hline Gale M. Sinatra & 12.25 & 2010 & 2019 \\
Thomas Holme & 7.00 & 2015 & 2017 \\
Ali Eryilmaz & 5.66 & 2002 & 2016 \\
Leman Tarhan & 5.25 & 2008 & 2013 \\
\hline
\end{tabular}


The list of the researchers in Table 2 shows that two Turkish researchers are among the top four as leading researchers in the field. Graph 7 displays the authors' countries.

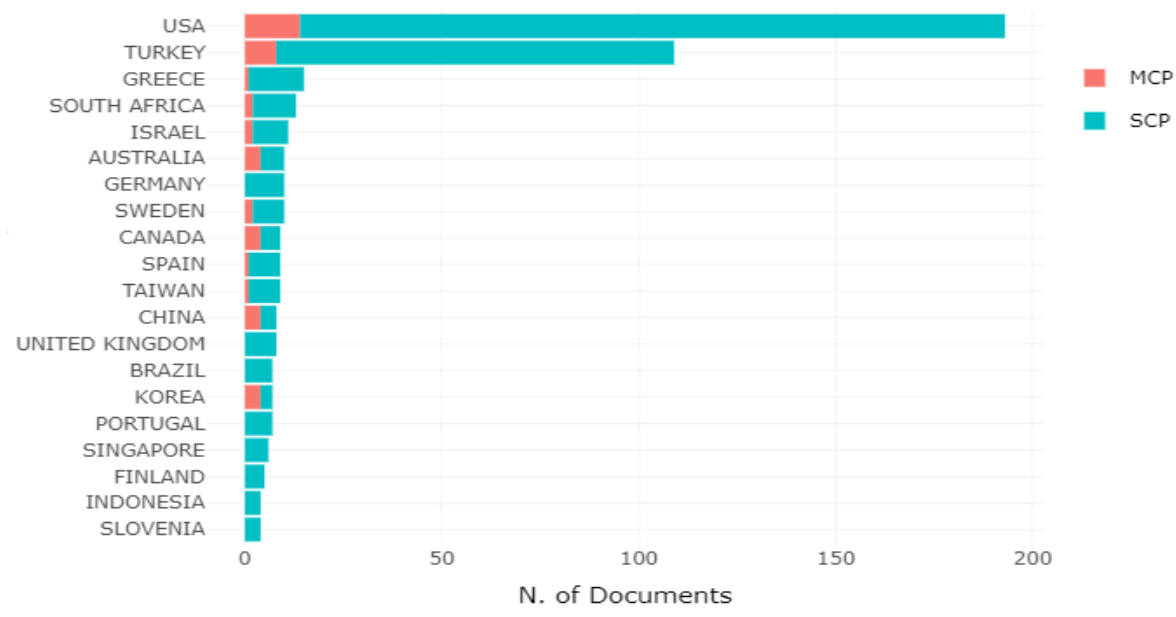

GRAPH 7.Corresponding authors' countries and the number of their articles

As displayed Graph 7, Single Country Publications (SCP) indicates the number of the articles published by the researchers from the same country whereas Multiple Country Publications (MCP) includes the articles published by the collaboration with other researchers from different countries. When considering the countries of the corresponding authors of these articles, it is noticed that the top three countries are USA with 193 articles (SCP: 179, MCP:14), Turkey with 109 articles (SCP:101, MCP:8), and Greece with 15 articles (SCP: 14, MCP: 1). Table 3 displays the first 20 countries of the corresponding authors based on the number of published articles.

Table 3.Number of articles per country and their SCP and MCP scores

\begin{tabular}{cccccc}
\hline Country & Articles & Frequency & SCP & MCP & MCP Ratio \\
\hline USA & 193 & 0.38677 & 179 & 14 & 0.0725 \\
TURKEY & 109 & 0.21844 & 101 & 8 & 0.0734 \\
GREECE & 15 & 0.03006 & 14 & 1 & 0.0667 \\
SOUTH AFRICA & 13 & 0.02605 & 11 & 2 & 0.1538 \\
ISRAEL & 11 & 0.02204 & 9 & 2 & 0.1818 \\
AUSTRALIA & 10 & 0.02004 & 6 & 4 & 0.4 \\
GERMANY & 10 & 0.02004 & 10 & 0 & 0 \\
SWEDEN & 10 & 0.02004 & 8 & 2 & 0.2 \\
CANADA & 9 & 0.01804 & 5 & 4 & 0.4444 \\
SPAIN & 9 & 0.01804 & 8 & 1 & 0.1111 \\
TAIWAN & 9 & 0.01804 & 8 & 1 & 0.1111 \\
CHINA & 8 & 0.01603 & 4 & 4 & 0.5 \\
UNITED KINGDOM & 8 & 0.01603 & 8 & 0 & 0 \\
BRAZIL & 7 & 0.01403 & 7 & 0 & 0 \\
KOREA & 7 & 0.01403 & 3 & 4 & 0.5714 \\
PORTUGAL & 7 & 0.01403 & 7 & 0 & 0 \\
SINGAPORE & 6 & 0.01202 & 6 & 0 & 0 \\
FINLAND & 5 & 0.01002 & 5 & 0 & 0 \\
INDONESIA & 4 & 0.00802 & 4 & 0 & 0 \\
SLOVENIA & 4 & 0.00802 & 4 & 0 & 0
\end{tabular}

Accordingly Table 3, USA and Turkey are placed in the first ranks; however, their MCP rates are rather at low levels. In other words, the authors from these countries conducted their research mostly with researchers from the same countries. Although Korea ranks as the 20th 
country in the list, it has the highest MCP rate. China is another country with a high MCP rate. These results demonstrate that the researchers in Korea and China are more open to international collaboration in research compared to the other researchers. It can also be seen that Germany, United Kingdom, Brazil, Portugal, Singapore, Finland, Indonesia, and Slovenia are the countries with the lowest MCP rates. Figure1 presents the results for the countries' scientific productivity rates.

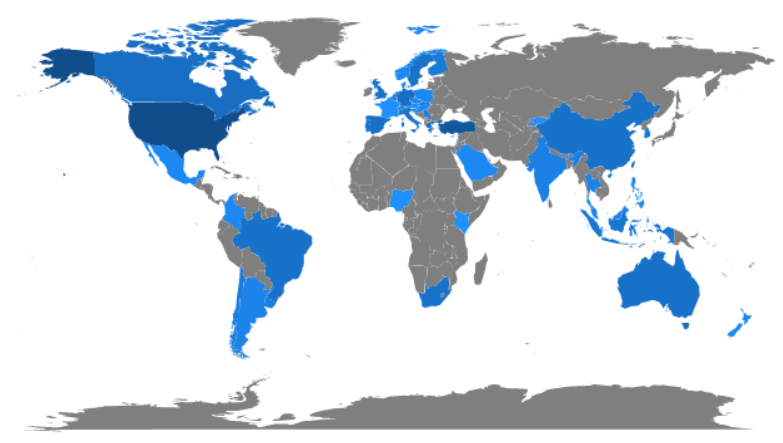

FIGURE1.Scientific productivity rates of the countries

The change in the colours in Figure 1 from dark blue towards light blue indicates the number of publications for the countries. The lighter blue gets, the fewer articles are published. The countries shown in grey colour do not have any publications indexed in databases. When the quantitative results in the map are analyzed, it can be seen that the first country is USA with 447 published articles, followed by Turkey with 171 articles. The third highest number of articles belongs to Greece with 26 published articles. Graph 8 shows countries receiving highest citation scores.

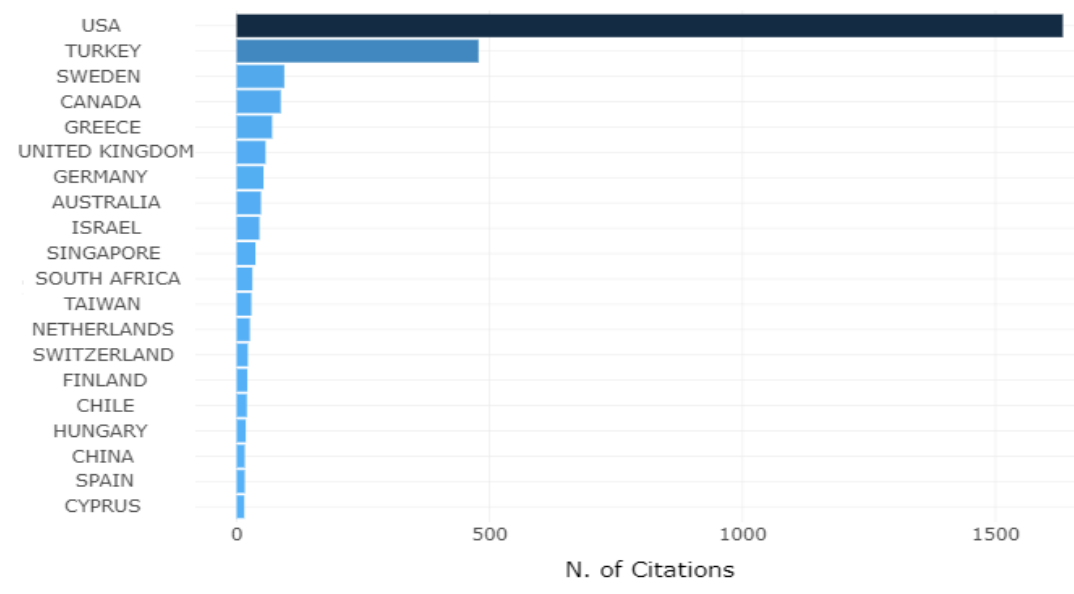

GRAPH 8.Countriesreceiving highest citation rates

Analyzing Graph 8, it is found that the countries with the highest citation scores are USA $(\mathrm{f}=1633)$, Turkey $(\mathrm{f}=478)$ and Sweden $(\mathrm{f}=94)$. Graph 9 displays the publications that have been cited the most. 


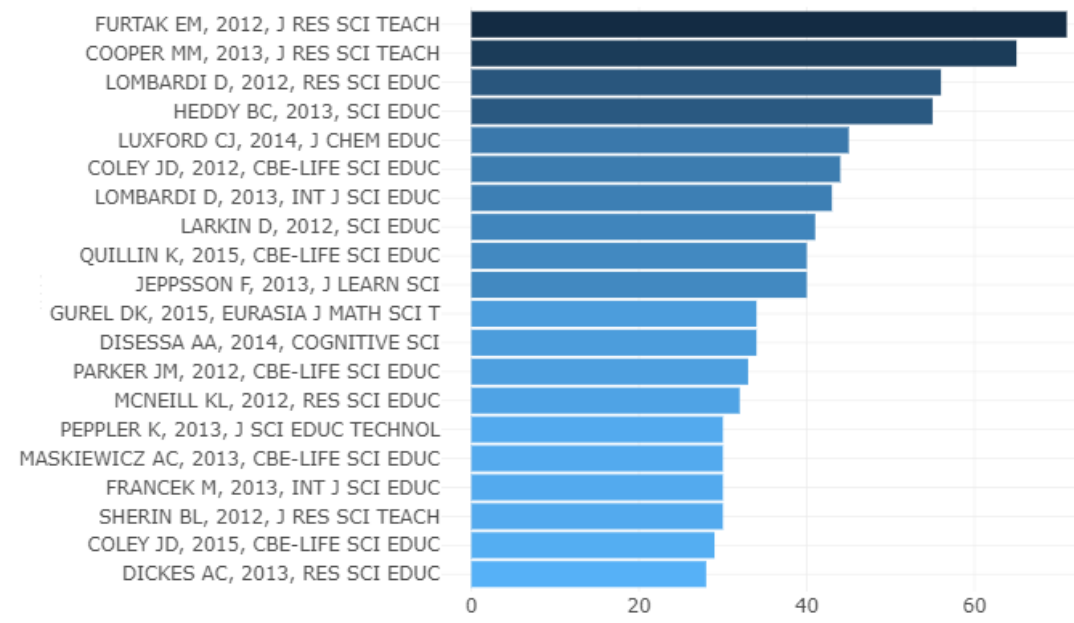

GRAPH 9.The most frequently cited publications

As displayed Graph 9, the articles related to "science misconception" keywords with the highest citation numbers. Accordingly, Furtak's (2012) article has the highest number of citations with 71, followed by Cooper, Corley and Underwood's (2013) article with 65 citations and with Lombardi and Sinatra's (2012) article with 56 citations. Figure 2 presents the most frequently used keywords in the articles.

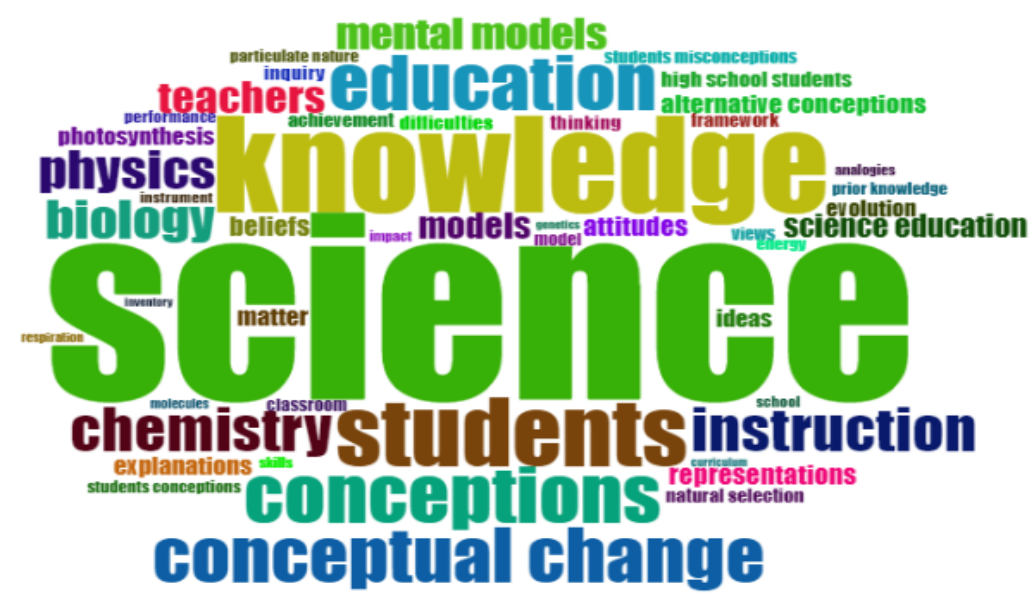

FIGURE 2: Word clouds

A word cloud is one of the text/data mining methods and is used to reveal the most frequently used words in a paragraph or a text. The word in the centre indicates the most frequently used word in the subject matter. The sizes of the words and their relative closeness to the centre reflect how frequently the words related to the subject matter have been used. As the size decreases and as the word is placed further from the centre, it is indicated that the word is used less commonly. Figure 2 reveals that the most commonly used words are science $(\mathrm{f}=216)$, knowledge $(\mathrm{f}=111)$, students $(\mathrm{f}=79)$, conceptions $(\mathrm{f}=66)$ and conceptual change $(\mathrm{f}=64)$. Figure 3 , on the other hand, shows the most frequently used words in the abstract sections of the analyzed articles. 


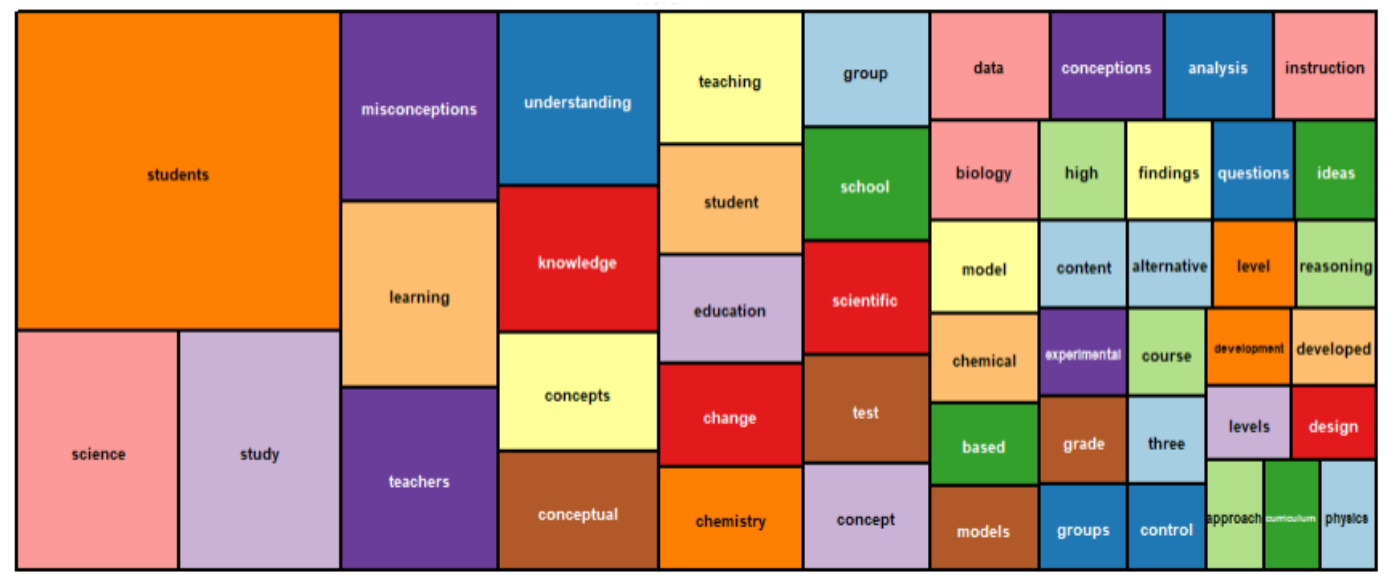

FIGURE 3: Word tree map

Word tree map is another method in text mining. It also shows the most commonly used words in a paragraph or a text. As the figure 3 displays, the most common words in these sections are students $(\mathrm{f}=2829)$, science $(\mathrm{f}=1069)$ and study $(\mathrm{f}=1064)$. Graph 10 displays the network of collaboration of the researchers who have published articles on the issue.

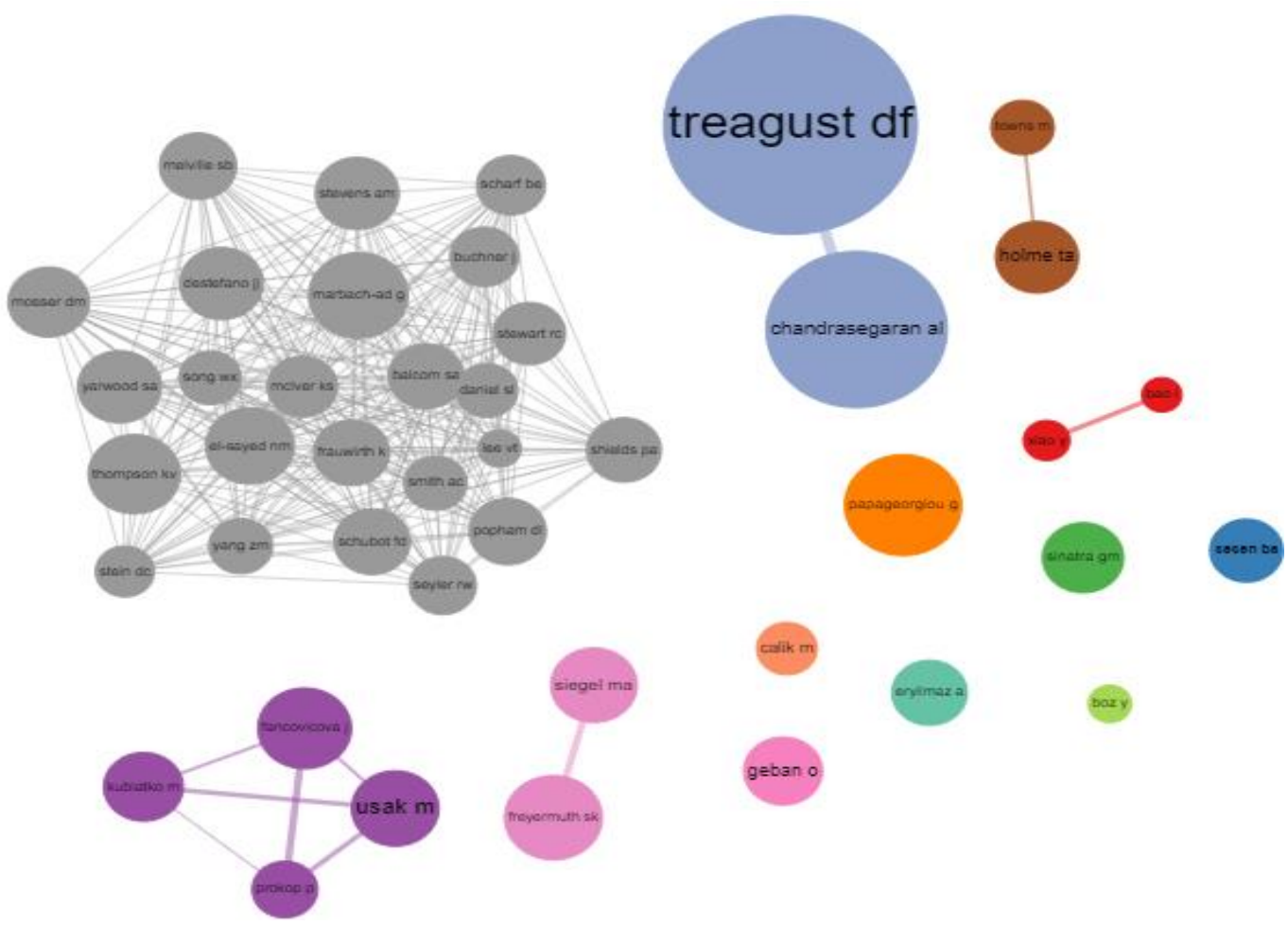

GRAPH10: Network of collaboration

As Graph 10 shows, the researchers who have collaborated in their research are grouped in the same cluster. According to Table 4, it can be stated that the researchers in the same cluster have articles in similar topics and have collaborated in their research. For example, when the articles of the researchers in cluster 8 are analyzed, it can be concluded that their research focus on similar topics and that they have collaborated in many of their studies. 
Table 4.Network of collaboration author-cluster values

\begin{tabular}{cccc}
\hline Author & Cluster & Author & Cluster \\
\hline Xiao y & 1 & Frauwirth k & 8 \\
Bao l & 1 & Lee vt & 8 \\
Cecen ba & 2 & Mclver ks & 8 \\
Sinatra gm & 3 & Melville sb & 8 \\
Fancovicova j & 4 & Mosser dm & 8 \\
Kubiatko m & 4 & Popham dl & 8 \\
Prokop p & 4 & Scharf be & 8 \\
Usak m & 4 & Schubot fd & 8 \\
Papageorgiou g & 5 & Seyler rw & 8 \\
Holme ta & 6 & Shields pa & 8 \\
Towns m & 6 & Song wx & 8 \\
Geban o & 7 & Stein dc & 8 \\
Stevens am & 8 & Stewart rc & 8 \\
Smith ac & 8 & Thompson kv & 8 \\
Marbach-ad g & 8 & Yang zm & 8 \\
Balcom sa & 8 & Yarwood sa & 8 \\
Buchner j & 8 & Eryilmaz a & 9 \\
Daniel sl & 8 & Calik m & 10 \\
Destefano jj & 8 & Treagust df & 11 \\
El-sayed nm & 8 & Chandrasegaran al & 11 \\
\hline
\end{tabular}

\section{DISCUSSION and CONCLUSIONS}

In the study, the articles accessed using "science misconception" keyword in Web of Science Core Collection database, which provides access to international publications and citations, were scanned. The scanning resulted in 2596 publications in total. Yet, following setting search limitations in line with the aim of the study, i.e., article, subject fields (science, physics, chemistry and biology teaching), and time period, 859 articles were selected for bibliometric analysis and were analyzed using R-Studio program. The analyses provided results regarding the annual distributions of the articles; the average citation scores; the list of the journals that published the highest number of related articles; the list of the authors that had published the highest number of related articles; the citation burst scores of the authors; the scientific productivity of the countries of the authors; the articles that were cited at the highest rates; collaboration networks; and their patterns that were obtained through text mining methods of word cloud and word tree.

According to the findings, the earliest article related to misconceptions in science in the database was published in 1986. The article titled "Can the history of science help science educators anticipate students' misconception" was published in Journal of Research in Science Teaching and by J. H. Wandersee. The number of related articles started to increase in 2006 and peaked between 2011 and 2015 (35.74\%). The highest number of articles on misconceptions was found to be in 2017 ( $\mathrm{f}=71$ ). On the other hand, the highest rate of annual average citation rate belongs to 2013 when 63 articles were published on misconceptions.

It has also been found that the authors who sought to publish articles on the topic preferred various journals. In total, 49 journals have been identified to have published articles on science misconceptions, yet, the highest number of articles belongs to "International Journal of Science Education" ( $\mathrm{f}=106$ ). The results also show that the other journals on the list are prestigious journals in the fields of science, physics, chemistry, and biology education.

The results also reveal that D. F. Treagust has been the author with the highest number of published articles on the topic, with 14 articles found in the database. The majority of Treagust's articles are in the fields of biology and chemistry while some of them focus on light, electricity, solar system, motion of planets and gravity. The Turkish authors with the highest number of published articles on the issue are Ö. Geban ( $\mathrm{f}=9$ ) and M. Çalık ( $\mathrm{f}=8)$. Although they 
have dealt with "science misconception" in various fields, it can be seen that their research has mostly addressed misconceptions in the field of chemistry.

Regarding the findings related to citation bursts, it has been identified that Sinatra has the highest burst score with his article titled "College students' perceptions about the plausibility of human induced climate change" published in Research in Science Education in 2012. However, having the highest citation burst score does not necessarily mean that the article has the highest number of citations. Rather, citation burst is more related to the density of the citations in a specific period of time. In the present study, burst scores were obtained from the analyzed 859 articles in Web of Science looking into their number of citations in the determined time period. As one of the leading researchers on the issue, D. F. Treagust has his highest citation burst score with his article titled "High school students' proficiency and confidence levels in displaying their understanding of basis electrolysis concepts" published in 2012 in International Journal of Science and Mathematics Education, which is still below Sinatra's burst score.

Another finding of the present study is that the highest number of articles related to science misconceptions are by the authors from America ( $\mathrm{f}=193$ ). Turkey follows as the second country in the list of related published articles $(\mathrm{f}=109)$. Researchers have been found to collaborate mostly with colleagues or researchers from their own countries. Researchers from Korea and China, on the other hand, are found to be more open to collaborations compared to the researchers from other countries. In addition, it has been revealed that the researchers from the Far East collaborate mostly with the researchers from America and the United Kingdom (e.g., Ha, Wei, Wang, Hou, \& Nehm, 2019; Nie et al., 2019; Seo, Park, \& Choi, 2017).

The issue of science misconceptions has also been found to attract researchers mostly from America, Turkey and Greece, thus, the researchers with the highest number of published articles on the issue are from these countries. Furthermore, the articles that are cited most frequently belong to the researchers from America. The article receiving the highest number of citations was 'Linking a learning progression for natural selection to teachers' enactment of formative assessment" by E. M. Furtak published in 2012 in Journal of Research in Science Teaching.

According to the findings obtained from word cloud and word tree analyses, the researchers most frequently used the terms "science" and "students" while searching for publications and writing the abstract sections as well. The other key words used in scanning databases include subject fields (physics, biology, chemistry) or focused sample groups (student and teachers) as well as teaching strategies (e.g. instruction, inquiry, models, conceptual change). As examples for the studies focusing on correcting misconceptions, the articles by Volfson, Eshach, \& Ben-Abu, 2019; Flynn \& Hardman, 2019; Martins-Louçao, Oliveira, Barata, \& Carvalho, 2019; Mathayas, Brown, Wallon, \& Lindgren, 2019 could be listed.

Lastly, the results related to collaboration network analyses show that the authors who have conducted joint research fall into the same cluster. Treagust is the most known of such authors and has two published articles conducted in collaboration with Chandrasegaran. Collaboration is found to aggregate mostly in cluster 8 , which is comprised of researchers from different countries. Moving from the findings of the present study, some suggestions could be made for further research in the field:

1. Researchers give importance to identifying and correcting misconception, and thus, it is suggested that research on this issue be continued.

2. Bibliometric analysis helps researchers to select areas for and to carry out research. The study is limited to published articles conducted using science misconception in the fields of science, physics, chemistry, and biology teaching. Researchers could conduct biometric analyses using various keywords in order to recognize fundamental research in the selected area of research and also to benefit from these publications. In addition, they could identify the journals that would be interested in publishing their research.

3. In this study, Web of Science Core Collection database index was used. The R Studio program is designed to be used only with Scopus and WoS databases. Thus, the study is limited to research found in Web of Science Core Collection database. Further studies could use other indexes such as Scopus, ProQuest, YOK Dissertation. 
4. The type of publication included in the sample of the study is limited to articles. Other publication types such as thesis, conference proceedings, or books could use in the analyses.

5. Further studies could be conducted using different limitations when searching for the articles. For example, the articles published only in specific journals or during specific time periods could be selected for the analyses.

\section{REFERENCES}

Akerson, V. L., Flick, L. B., \& Lederman, N. G. (2000). The influence of primary children's ideas in science on teaching practice. Journal of Research in Science Teaching, 37 (4), 363-385.

Al, U., Soydal, İ., \& Yalçın, H. (2010). Bibliyometriközellikleriaçisindanbilig'indeğerlendirilmesi.Bilig, Güz, $55,1-20$.

Allen, M. (2010). Misconceptions in primary science. Open University Press, Maidenhead, GBR. Online available:http://site.ebrary.com.libproxy.library.wmich.edu/lib/wmichlib/docDetail.action?docID=10 403990

Allen, M. \& Coole, H. (2012). Experimenter confirmation bias and the correction of science misconceptions. Journal of Science Teacher Education, 23 (4), 387-405.

Altnnulluk, H. (2018). Examination of theses on augmented reality in Turkey through bibliometric analysis method. Eğitim Teknolojisi Kuram ve Uygulama, 8(1), 248-272.

Aria, M. \& Cuccurullo, C. (2017). Bibliometrix: An R-tool for comprehensive science mapping analysis. Journal of Informetrics, 11(4), 959-75.

Berkant, H. G. (2007). Dokuzuncu sınıf biyoloji dersinde yapıcı öğrenme temelli hazırlanan anlamlı nedensel düşünmeye dayalı öğretimin öğrencilerin anlamlı nedensel düşünmelerine, akademik başarılarına, kalıclığa ve günlük yaşam davranışlarına etkisi [The effect of constructivist learning based meaningful causal thinking instruction in nineth grade biology lesson on students' meaningful causal thinking, academic achievements, retention and everyday lives behaviours].PhD thesis, Çukurova Üniversitesi, Sosyal Bilimler Enstitüsü, Adana.

Bookstein, A. (1980). Explanations of the bibliometric laws. Collection Management, 3(2-3), 151-162.

Büyüköztürk, Ş., Kılıç-Çakmak, E., Akgün, Ö.E., Karadeniz, Ş., \& Demirel, F. (2017). Bilimsel araştırma yöntemleri. Ankara: Pegem Yayınları.

Committee on Undergraduate Science Education (1997). Science teaching reconsidered: A handbook. National Academy Press, Retrieved from http://www.nap.edu/catalog.php?record_id=5287\#toc.

Cooper, M. M., Corley, L. M., \& Underwood, S. M. (2013). An investigation of college chemistry students' understanding of structure-property relationships. Journal of Research in Science Teaching, 50, 699- 721.

Dinçer, S. (2014). Eğitim bilimlerinde uygulamalı meta-analiz [Applied meta-analysis in educational sciences]. Pegem Atı İndeksi, 2014(1), 1-133.

Duit, R. (2002) Bibliography STCSE: Students' and teachers' conceptions and science education. Kiel, Germany: IPN - Leibniz Institute for Science Education. Online available: https://www.if.ufri.br/ marta/aprendizagememfisica/fv09.pdf

Doğru, M., Güzeller, C. O., \& Celik, M. (2019). A bibliometric analysis in the field of sustainable development and education from past to present. Adlyaman University Journal of Educational Sciences, 9(1), 42-68.

Erduran, S., Kaya, E., \& Cetin, P. S. (2018). Consolidation of conceptual change, argumentation, models and explanations. (Editors: Tamer G. Amin \& Olivia Levrini) Converging perspectives on conceptual change: mapping an emerging paradigm in the learning sciences. Abingdon, Routledge.

Eryilmaz, A. (2002). Effects of conceptual assignments and conceptual change discussions on students' misconceptions and achievement regarding force and motion. Journal of Research in Science Teaching, 39, 1001-1015.

Eymur, G. \& Geban, Ö. (2017). The collaboration of cooperative learning and conceptual change: Enhancing the students' understanding of chemical bonding concepts. International Journal of Science and Mathematics Education, 15 (5), 853-871.

Flynn, S. \& Hardman, M. (2019). The use of interactive fiction to promote conceptual change in science. Science \& Education, 28(1-2), 127-152.

Furtak, E. M. (2012). Linking a learning progression for natural selection to teachers' enactment of formative assessment. Journal of Research in Science Teaching, 49(9), 1181-1210. 
Gomez-Zwiep, S. (2008). Elementary teachers' understanding of students' science misconceptions: Implications for practice and teacher education. Journal of Science Teacher Education, 19, 437-454.

Gooding, D. \& Metz, B. (2011). From misconceptions to conceptual change. The Science Teacher, April/May 2011, 34-37.

Güzeller, C. O. \& Çeliker, N. (2017). Gastronomy from past to today: A bibliometric analysis.Journal of Tourism and Gastronomy Studies, 5/Special Issue2, 88-102.

Ha, M., Wei, X., Wang, J., Hou, D., \& Nehm, R. H. (2019). Chinese pre-service biology teachers' evolutionary knowledge, reasoning patterns, and acceptance levels. International Journal of Science Education, 41(5), 628-651.

Hernandez-Torrano, D. \& Ibrayeva, L. (2020). Creativity and education: A bibliometric mapping of the research literature (1975-2019). Thinking Skills and Creativity, 35 (2020), 100625.

Huang, I. (1931). Children's explanations of strange phenomena. Psychologische Forschung, 14,63-182.

Huang, Y.L., Ho, Y.S., \& Chuang, K.Y. (2006). Bibliometric analysis of nursing research in Taiwan 19912004. Journal of Nursing Research, 14, 75-81.

Jimenez, C.R., Prieto, M.S., \& Garcia, S.A. (2019). Technology and higher education: A bibliometric analysis. Education Sciences, 9(3), 169.

Jho, H. (2018). Trends in research on the nature of science: A bibliometric analysis with R-mapping tool. Journal of Learner-Centered Curriculum and Instruction, 18(18), 937-956.

Karaboğa, H. A. (2019). Örgütsel davranış araştırmalarının bibliyometrik analizi [A bibliometric analysis of research on organizational behaviour]. Master's thesis, Yıldız Teknik Üniversitesi, Sosyal Bilimler Enstitüsü, İstanbul.

Khodabandelou, R., Mehran, G., \& Nimehchisalem, V. (2018). A bibliometric analysis of $21^{\text {st }}$ century research trends in early childhood education. Revista Publicando, 5(15), 137-163.

Larkin, D. (2012). Misconceptions about "misconceptions": Preservice secondary science teachers' views on the value and role of student ideas. Science Education, 96 (5), 927-959.

Lin, J. W., Yen, M. H., Liang, J. C., Chiu, M. H., \& Guo, C. J. (2016). Examining the factors that influence students' science learning processes and their learning outcomes: 30 years of conceptual change research. Eurasia Journal of Mathematics, Science \& Technology Education, 12(9), 2617-2646.

Lombardi, D. \& Sinatra, G. M. (2012). College students' perceptions about the plausibility of humaninduced climate change. Research in Science Education, 42, 201-217.

Lopes, R. M., Fidalgo-Neto, A. A., \& Mota, F. B. (2017). Facebook in educational research: A bibliometric analysis. Scientometrics, 111(3), 1591-1621.

Martins-Louçao, M.A., Gaio-Oliveira, G., Barata, R., \& Carvalho, N. (2019). Inquiry-based science learning in the context of a continuing professional development programme for biology teachers. Journal of Biological Education, 1-17.

Mason, L., Baldi, R., Ronco, S. D., Scrimin, S., Danielson, R. W., \& Sinatra, G. L. (2017). Textual and graphical refutations: Effects on conceptual change learning. Contemporary Educational Psychology, 49 (2017), 275-288.

Mathayas, N., Brown, D. E., Wallon, R. C., \& Lindgren, R. (2019). Representational gesturing as an epistemic tool for the development of mechanistic explanatory models. Science Education, 103(4), 10471079.

Nie,Y., Xiao,Y., Fritchman, J.C., Lıu,Q., Han, J., Xiong, J., \& Bao,L. (2019). Teaching towards knowledge integration in learning force and motion. International Journal of Science Education, 41, 2271-2295.

Özkaya, A. (2019). Bibliometric analysis of the publications made in STEM education area. Bartın University Journal of Faculty of Education, 8(2), 590-628.

Posner, G.J., Strike, K.A., Hewson, P.W., \& Gertzog, W.A. (1982). Accommodation of a scientific conception: Toward a theory of conceptual change. Science Education, 66 (2), 221-227.

Seo, K., Park, S., \& Choi, A. (2017). Science teachers' perceptions of and approaches towards students' misconceptions on photosynthesis: a comparison study between US and Korea. EURASIA Journal of Mathematics Science and Technology Education, 30 (1), 269-296.

Sia, D.T., Treagust, D.F., \& Chandrasegaran, A.L. (2012). High school students' proficiency and confidence levels in displaying their understanding of basic electrolysis concepts. International Journal of Science and Mathematics Education, 10, 1325-1345.

Sinatra, G. M. (2005). The "warming trend" in conceptual change research: The legacy of Paul R. Pintrich. Educational Psychologist, 40 (2), 107-115.

Southerland, S., Abrams, E., Cummins, C., \& Anzelmo, J. (2001). Understanding students' explanations of biological phenomena: Conceptual frameworks or p-prims? Science Education, 85, 328-348.

Tang, K.Y., Hsiao, C.H., \& Su, Y.S. (2019). Networking for educational innovations: A bibliometric survey of international publication patterns. Sustainability, 11, 4608. 
Treagust, D. F., Duit, R., \& Fischer, H. E.(2017).Multiple representations in physics education. Springer. Volfson, A., Eshach, H., \& Ben-Abu, Y. (2019). Introducing the idea of entropy to the ontological category shift theory for conceptual change: The case of heat and sound. Physical Review Physics Education Research, 15, 1-12.

Wandersee, J.H. (1986). Can the history of science help science educators anticipate students'misconceptions? Journal of Research in Science Teaching, 23, 581-597.

Wesson, K. (2001). What recent brain research tells us about learning? Independent School, 61(1), 58-69.

Ye, J., Chen D., \& Kong, L. (2019). Bibliometric analysis of the WoS literature on research of science teacher from 2000 to 2017. Journal of Baltic Science Education, 18(5), 732-747. 